Corrigendum

\title{
Corrigendum to "Ferulic Acid Induces Th1 Responses by Modulating the Function of Dendritic Cells and Ameliorates Th2-Mediated Allergic Airway Inflammation in Mice"
}

\author{
Chen-Chen Lee, ${ }^{1}$ Ching-Chiung Wang, ${ }^{2}$ Huei-Mei Huang, ${ }^{3}$ Chu-Lun Lin, ${ }^{3}$ \\ Sy-Jye Leu, ${ }^{4}$ and Yueh-Lun Lee ${ }^{4}$ \\ ${ }^{1}$ Department of Microbiology and Immunology, School of Medicine, China Medical University, Taichung 40402, Taiwan \\ ${ }^{2}$ School of Pharmacy, College of Pharmacy, Taipei Medical University, Taipei 11031, Taiwan \\ ${ }^{3}$ Graduate Institute of Medical Sciences, College of Medicine, Taipei Medical University, Taipei 11031, Taiwan \\ ${ }^{4}$ Department of Microbiology and Immunology, School of Medicine, College of Medicine, Taipei Medical University, \\ Taipei 11031, Taiwan
}

Correspondence should be addressed to Yueh-Lun Lee; yllee@tmu.edu.tw

Received 26 July 2017; Accepted 6 August 2017; Published 20 September 2017

Copyright (C) 2017 Chen-Chen Lee et al. This is an open access article distributed under the Creative Commons Attribution License, which permits unrestricted use, distribution, and reproduction in any medium, provided the original work is properly cited.

In the article titled "Ferulic Acid Induces Th1 Responses by Modulating the Function of Dendritic Cells and Ameliorates Th2-Mediated Allergic Airway Inflammation in Mice" [1], affiliation number four was given incorrectly. The corrected affiliation is shown above.

\section{References}

[1] C.-C. Lee, C.-C. Wang, H.-M. Huang, C.-L. Lin, S.-J. Leu, and Y.-L. Lee, "Ferulic acid induces Th1 responses by modulating the function of dendritic cells and ameliorates Th2-mediated allergic airway inflammation in mice," Evidence-Based Complementary and Alternative Medicine, vol. 2015, Article ID 678487, 16 pages, 2015. 


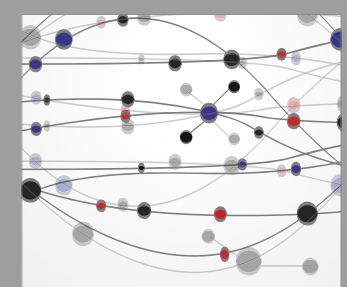

The Scientific World Journal
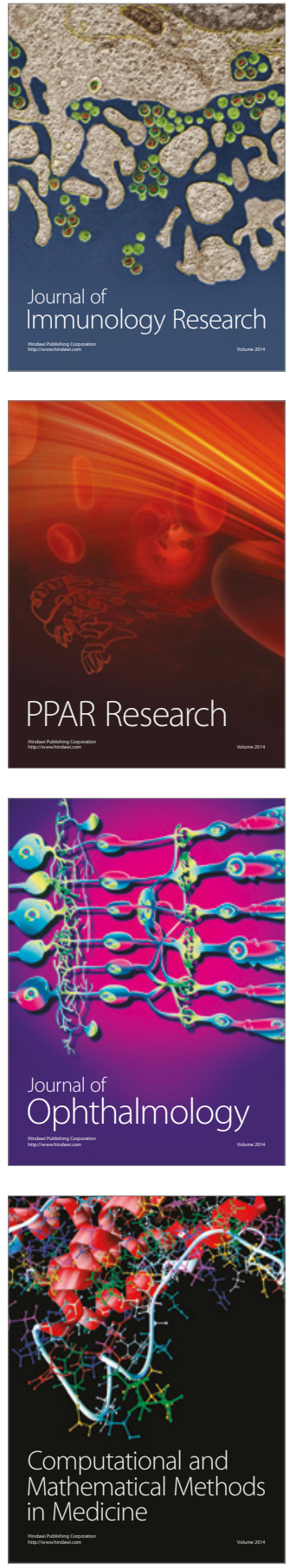

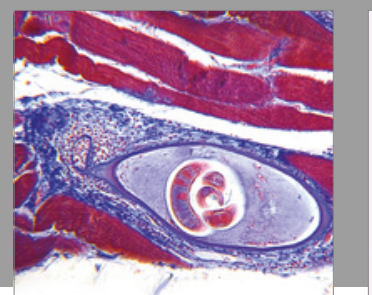

Gastroenterology Research and Practice
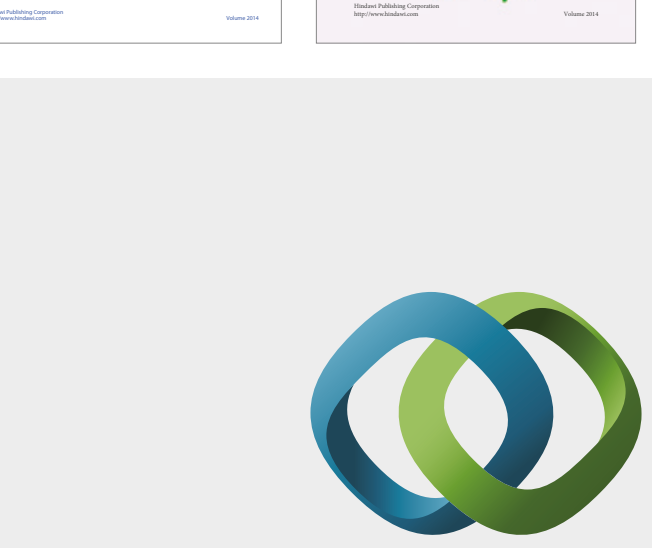

\section{Hindawi}

Submit your manuscripts at

https://www.hindawi.com
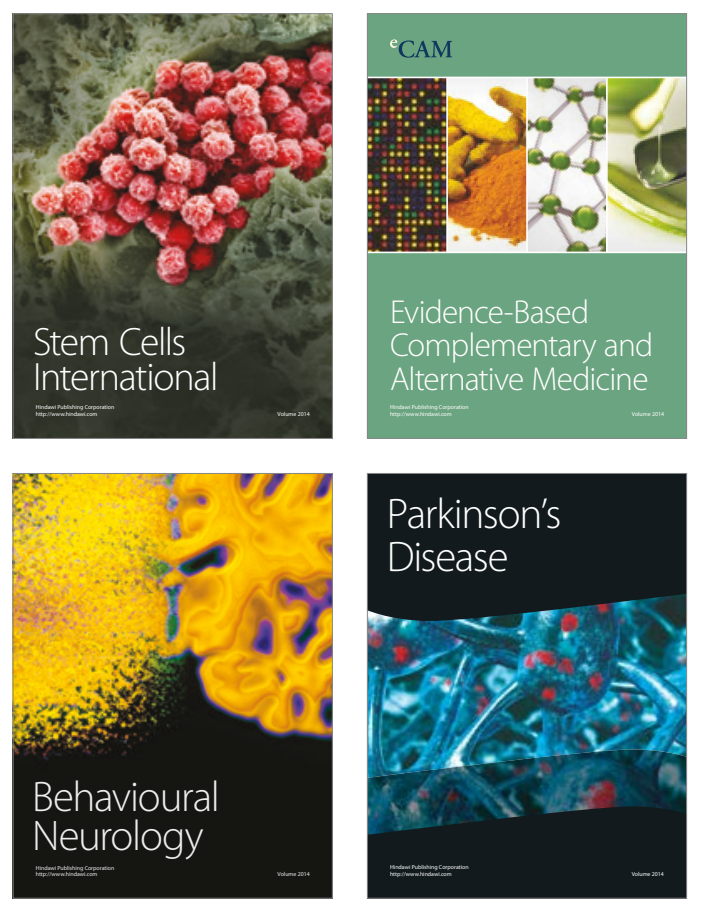
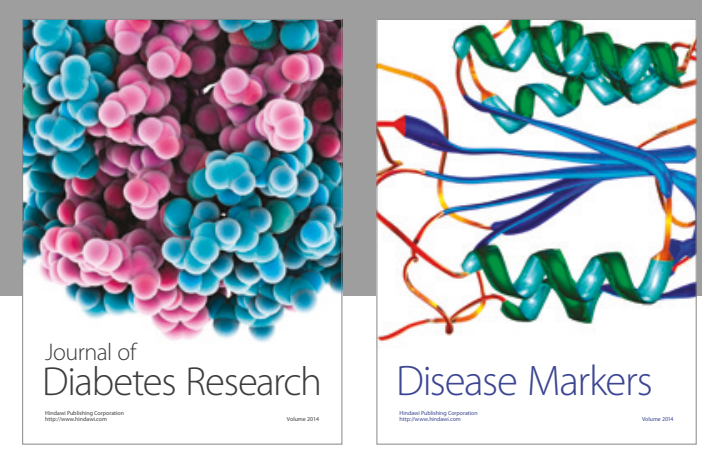

Disease Markers
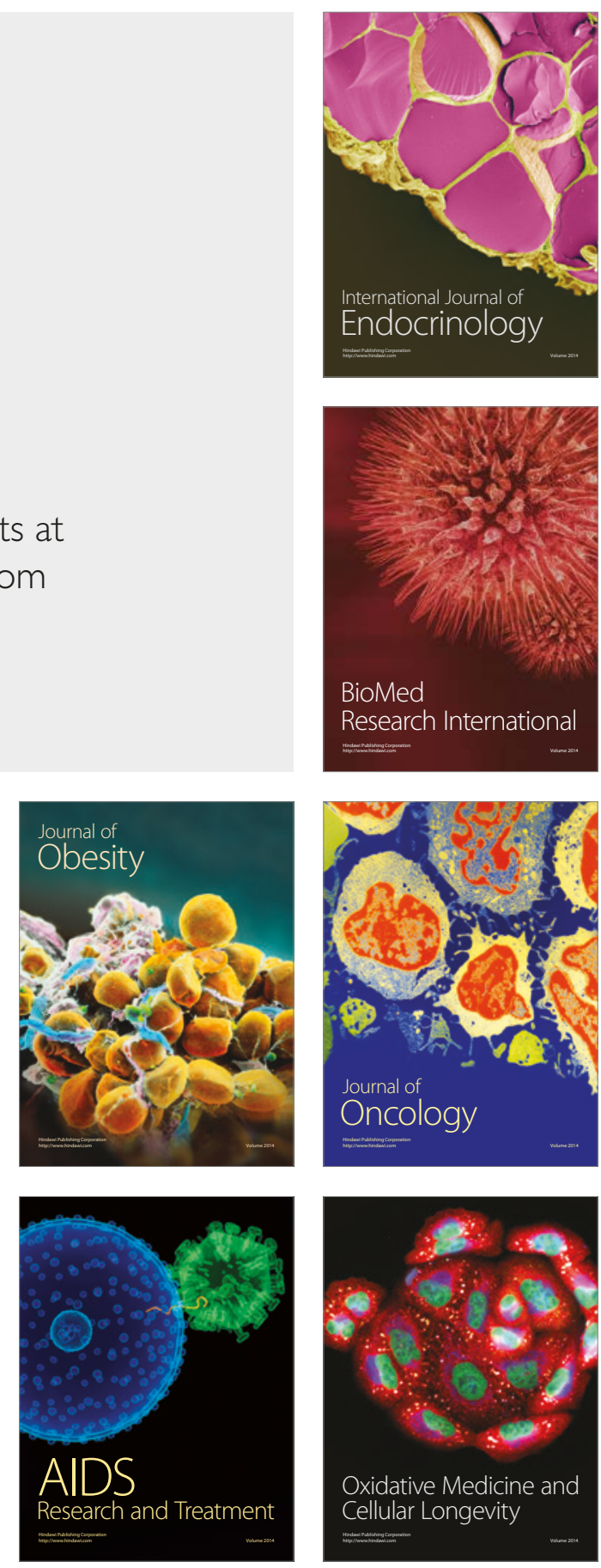